\title{
An inventory of avian species in Aldesa Valley, Saudi Arabia
}

\author{
Abdulaziz S. Alatawi ${ }^{1}$, Florent Bled ${ }^{1}$, Jerrold L. Belant ${ }^{2}$ \\ 1 Mississippi State University, Forest and Wildlife Research Center, Carnivore Ecology Laboratory, Box 9690, Mississippi State, MS, USA 39762. \\ 2 State University of New York, College of Environmental Science and Forestry, 1 Forestry Drive, Syracuse, NY, USA 13210. \\ Corresponding author: Abdulaziz S. Alatawi, abalatawi@ut.edu.sa
}

\begin{abstract}
Conducting species inventories is important to provide baseline information essential for management and conservation. Aldesa Valley lies in the Tabuk Province of northwest Saudi Arabia and because of the presence of permanent water, is thought to contain high avian richness. We conducted an inventory of avian species in Aldesa Valley, using timed area-searches during May 10-August 10 in 2014 and 2015 to detect species occurrence. We detected 6860 birds belonging to 19 species. We also noted high human use of this area including agriculture and recreational activities. Maintaining species diversity is important in areas receiving anthropogenic pressures, and we encourage additional surveys to further identify species occurrence in Aldesa Valley.
\end{abstract}

\section{Key words}

Arabian Peninsula; bird inventory; desert fauna.

Academic editor: Mansour Aliabadian | Received 21 April 2016 | Accepted 27 May 2018 | Published 14 September 2018

Citation: Alatawi AS, Bled F, Belant JL (2018) An inventory of avian species in Aldesa Valley, Saudi Arabia. Check List 14 (5): 743-750. https:// doi.org/10.15560/14.5.743

\section{Introduction}

Global biodiversity is a consequence of evolutionary events that occur over time and space (Jetz et al. 2012). With current rates of biodiversity loss, understanding factors influencing species richness is critical (Sala et al. 2000, Pimm et al. 2014). Loss of biodiversity can directly and adversely alter ecosystem processes which in turn can affect the resilience of ecosystems to environmental changes (Chapin et al. 2000). For instance, modifications in biodiversity may affect species traits and community composition, for example by the introduction of exotic species (Vitousek et al. 1997). Species composition and interactions between species, as well as abiotic factors, are the fundamental elements in any ecosystem (Groombridge and Jenkins 2002), with losses in biodiversity threatening ecosystems and the species communities living therein (Balvanera et al. 2006). Conservation of biodiversity is essential to ensure that ecosystems persist and function properly (Chapin et al. 2000). Biodiversity losses can be irreversible; therefore, biodiversity should be monitored and protected (Chapin et al. 2000, Brooks et al. 2006), and conducting species inventories are the most common approach to survey species richness (Hill et al. 2005).

Considerable variation in species richness exists, depending on ecological factors, with areas receiving higher rainfall having greater richness than dry areas, such as deserts (Gaston 2000). Deserts are defined as any ecosystem where limited water affects occurrence of species (Lawrence 2004), and desert ecosystems often contain the lowest species abundance and productivity (Waide et al. 1999). Hence, diversity and richness of terrestrial species in deserts are constrained by low rainfall, 


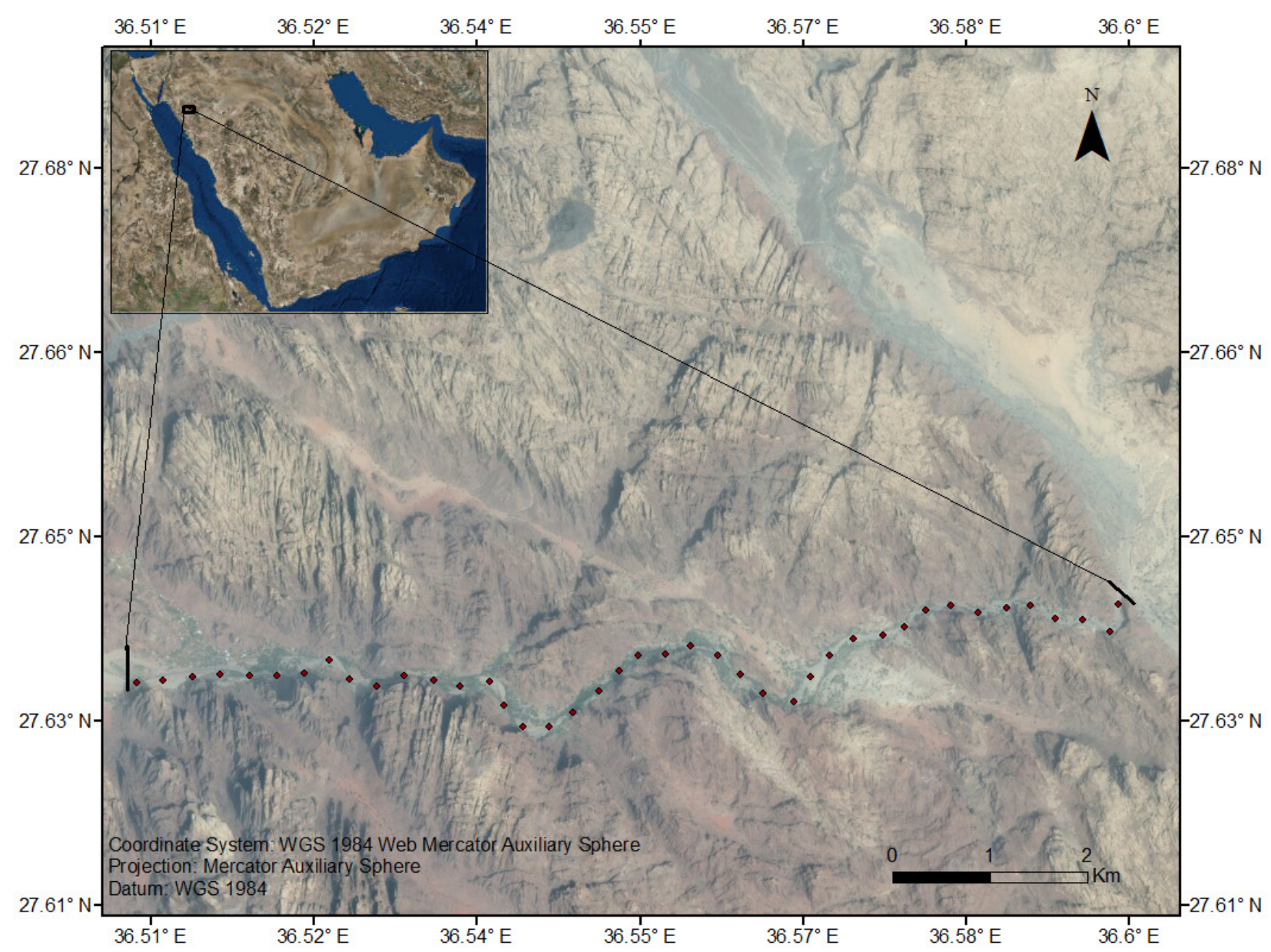

Figure 1. Aldesa Valley, Tabuk Region, Saudi Arabia shown above between the 2 black lines. Points in the valley represent the 40 segments locations.

but high temperature also has a strong effect on species occurrence in deserts (Tiger and Osborne 1999, Gillman and Wright 2014). Species richness is influenced by geographical composition (Brown et al. 2007), with valleys in deserts containing typically greater plant diversity, which in turn results in greater species richness of vertebrates (Qian 2007). Water may be more important to species where drought is continuous (AbuZinada et al. 2004). Access to water and related vegetation offered by desert valleys provide a higher quality habitat in terms of food and shelter for species (Slattery et al. 2003, Korine et al. 2015).

Conservation programs often tend to emphasize regions with greater species richness, with most national and international conservation efforts occurring in these areas (Fa and Funk 2007). In contrast, comparatively few efforts are conducted in areas of low species richness, such as deserts. Though deserts do not typically support high species diversity (Walker 1992, Lawrence 2004), documenting and maintaining biodiversity in ecosystems with low diversity is important because it provides important information about species existence and richness which can be used to ensure the long-term persistence of species assemblages in these extreme conditions (AbuZinada et al. 2004).

In 2001, the Kingdom of Saudi Arabia became sig- natory to the Convention of Conservation on Biological Diversity that seeks to ensure the conservation of species and their habitats for all time (AbuZinada et al. 2004). In Saudi Arabia, 432 bird species belonging to 67 families have been recorded (AbuZinada et al. 2004). The Aldesa Valley is a unique ecosystem in Tabuk Province as the availability of water and the complex vegetation likely supports diverse bird species. Our objective was to inventory the avian species richness in the Aldesa Valley.

\section{Methods}

Study site. The Aldesa Valley is a narrow, $10 \mathrm{~km}$ long valley between 2 minor mountain ranges about $225 \mathrm{~km}$ southwest of Tabuk City, Saudi Arabia (Fig. 1). Aldesa Valley contains a permanent spring, known as the Blue or Eye Fountain. Temperatures during winter (December-February) typically range from 2 to $15^{\circ} \mathrm{C}$, but are occasionally below $0{ }^{\circ} \mathrm{C}$. Temperatures during summer range from 19 to $42{ }^{\circ} \mathrm{C}$ in May and 24 to $48^{\circ} \mathrm{C}$ in July. Annual rainfall is about $35 \mathrm{~mm}$ (Gosling et al. 2011).

Data collection. We conducted fieldwork from 10 May to 10 August in 2014 and 2015, having received permission from the Province of Tabuk and the University of Tabuk. We divided the valley, which is oriented east to west, into 40, $250 \mathrm{~m}$ long segments (Fig. 1). Each seg- 
ment was surveyed perpendicular to the valley (i.e. north to south), twice in 2014 and 3 times in 2015. We used timed area searches (timed counts) to quantify bird species occurrence, conducting searches from 06:30-10:00 $\mathrm{h}$ and arriving at the first segment $15 \mathrm{~min}$ before sunrise (Hill et al. 2005, Shirley et al. 2013). We conducted surveys when winds were $<12 \mathrm{~km} / \mathrm{hr}$ and there was no rain (Ralph et al. 1995). We used a handheld anemometer (EA-3010U Handheld Travel Anemometer) to record wind speed and temperature during surveys. We searched segments for $0.5-2.0 \mathrm{~h}$, with time spend depending on segment size and the complexity of vegetation, and using a predetermined schedule. We surveyed 4 or 5 segments each day. We used 2 field guides to aid in the identification of birds (Porter and Aspinall 2010, Pope and Zogaris 2012). For each observation, we recorded the time and the number of individuals by species. We made additional opportunistic observations outside of our timed searches.

We used the IUCN Red List of Threatened Species (IUCN 2016) to determine the global conservation status for each species to provide an indication of the importance of the Aldesa Valley to vertebrate biodiversity within Saudi Arabia. We present the total number of times each species has been detected, as well as the number of segments in which each species was detected in each survey.

\section{Results}

We observed 2906 bird occurrences in 2014 and 3954 in 2015 belonging to 19 species, 15 families, and 5 orders (Fig. 2; Table 1). The most commonly detected bird species in Aldesa Valley were Passer domesticus (Linnaeus, 1758) representing 29.2\% of all birds detected; Onychognathus tristramii (Sclater, 1858), 16.3\% of detections; Spilopelia senegalensis (Linnaeus, 1766), 15.7\% of detections; Pycnonotus xanthopygos (Hemprich \& Ehrenberg, 1833); Figure 6), 8.6\% of detections; Carpodacus synoicus Temminck, 1825), 6.6\% of detections; and Cinnyris osea (Bonaparte, 1856), 6.5\% of detections.

Family Passeridae

Passer domesticus (Linnaeus, 1758), House Sparrow Figure 3

Porter and Aspinall (2010): 324; Pope and Zogaris (2012): 366; ITIS (2016).

Material examined. Table 1; field observations and photographs.

Identification. This is a small common species ubiquitous to Aldesa Valley. The male has a gray crown, brown sides, a black bib, and white cheeks. The female is

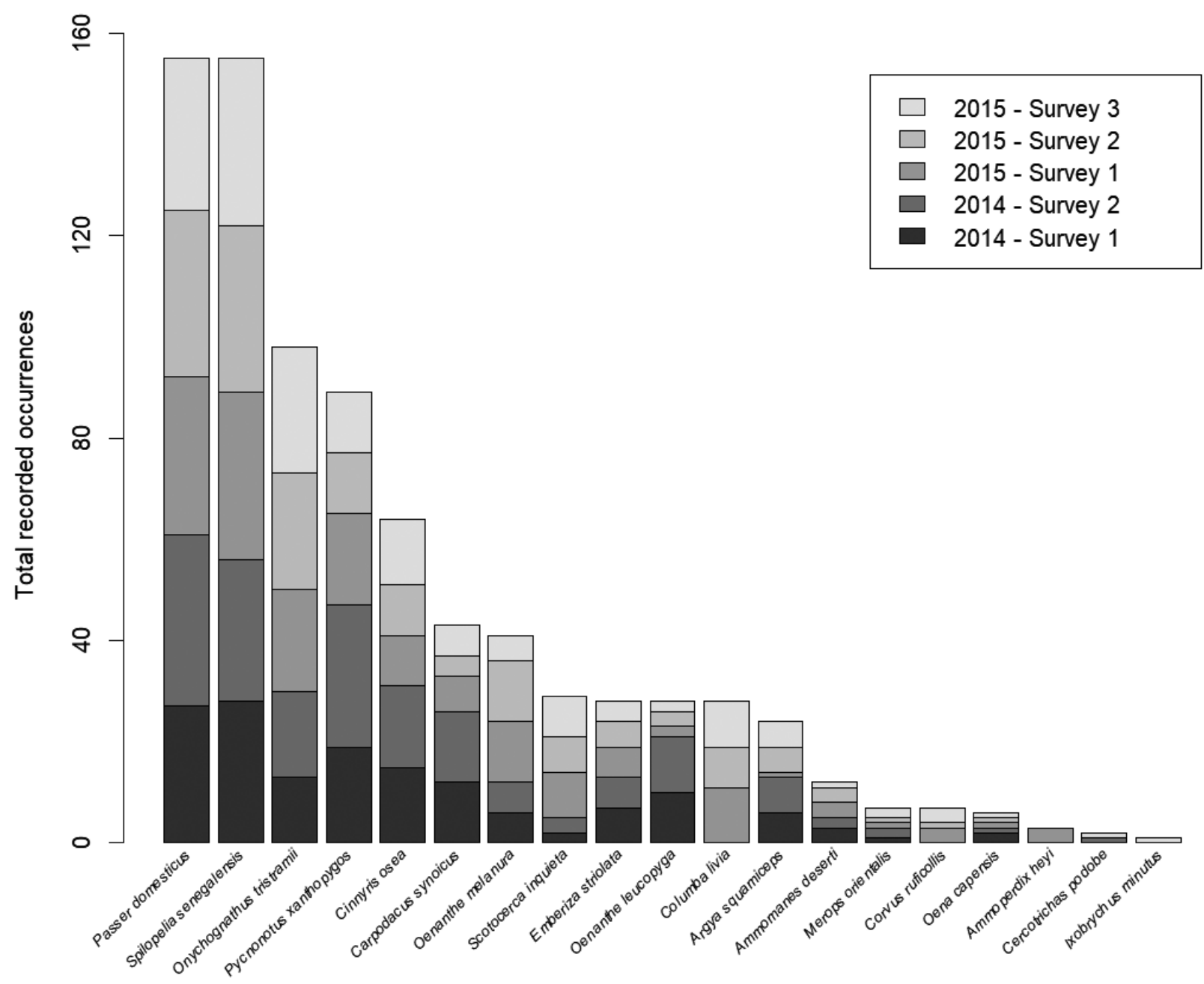

Figure 2. Total number of occurrences, and detail per survey, for bird species that were detected in the Aldesa Valley from 10 May to 10 August in 2014 and 2015. 
Table 1. Avian species observed in Aldesa Valley, Saudi Arabia from 10 May to 10 August in 2014 and 2015.

\begin{tabular}{|c|c|c|c|c|}
\hline \multirow{2}{*}{ Taxon } & \multirow{2}{*}{ IUCN status' } & \multicolumn{2}{|c|}{ No. of detections } & \multirow{2}{*}{ Total } \\
\hline & & 2014 & 2015 & \\
\hline \multicolumn{5}{|l|}{ Aves } \\
\hline \multicolumn{5}{|l|}{ Passeriformes } \\
\hline \multicolumn{5}{|l|}{ Passeridae } \\
\hline Passer domesticus (Linnaeus, 1758) & LC & 843 & 1163 & 2006 \\
\hline \multicolumn{5}{|l|}{ Pycnonotidae } \\
\hline Pycnonotus xanthopygos (Hemprich \& Ehrenberg, 1833) & LC & 223 & 365 & 588 \\
\hline \multicolumn{5}{|l|}{ Sturnidae } \\
\hline Onychognathus tristramii (Sclater, 1858) & LC & 439 & 682 & 1121 \\
\hline \multicolumn{5}{|l|}{ Nectariniidae } \\
\hline Cinnyris osea (Bonaparte, 1856) & LC & 116 & 330 & 446 \\
\hline \multicolumn{5}{|l|}{ Muscicapidae } \\
\hline Oenanthe melanura (Temminck, 1824) & LC & 89 & 76 & 165 \\
\hline Oenanthe leucopyga (Brehm, 1855) & LC & 18 & 56 & 74 \\
\hline Cercotrichas podobe (Müller, 1776) & LC & 0 & 4 & 4 \\
\hline \multicolumn{5}{|l|}{ Scotocercidae } \\
\hline Scotocerca inquieta (Cretzschmar, 1827) & LC & 239 & 154 & 393 \\
\hline \multicolumn{5}{|l|}{ Corvidae } \\
\hline Corvus ruficollis Lesson, 1830 & LC & 22 & 19 & 41 \\
\hline \multicolumn{5}{|l|}{ Fringillidae } \\
\hline Carpodacus synoicus (Temminck, 1825) & LC & 322 & 131 & 453 \\
\hline \multicolumn{5}{|l|}{ Leiotrichidae } \\
\hline Argya squamiceps (Cretzschmar, 1827) & LC & 57 & 60 & 117 \\
\hline \multicolumn{5}{|l|}{ Alaudidae } \\
\hline Ammomanes deserti (Lichtenstein, 1823) & LC & 0 & 90 & 90 \\
\hline \multicolumn{5}{|l|}{ Emberizidae } \\
\hline Emberiza striolata (Lichtenstein, 1823) & LC & 66 & 36 & 102 \\
\hline \multicolumn{5}{|l|}{ Columbiformes } \\
\hline \multicolumn{5}{|l|}{ Columbidae } \\
\hline Spilopelia senegalensis (Linnaeus, 1766) & LC & 419 & 657 & 1076 \\
\hline Oena capensis (Linnaeus, 1766) & LC & 8 & 5 & 13 \\
\hline Columba livia Gmelin, 1789 & LC & 15 & 78 & 93 \\
\hline \multicolumn{5}{|l|}{ Pelecaniformes } \\
\hline \multicolumn{5}{|l|}{ Ardeidae } \\
\hline Ixobrychus minutus (Linnaeus, 1766) & LC & 1 & 2 & 3 \\
\hline \multicolumn{5}{|l|}{ Coraciiformes } \\
\hline \multicolumn{5}{|l|}{ Meropidae } \\
\hline Merops orientalis Latham, 1801 & LC & 20 & 13 & 33 \\
\hline \multicolumn{5}{|l|}{ Galliformes } \\
\hline \multicolumn{5}{|l|}{ Phasianidae } \\
\hline Ammoperdix heyi (Temminck, 1825) & LC & 9 & 33 & 42 \\
\hline
\end{tabular}

${ }^{1} \mathrm{LC}=$ Least Concern

brown-gray on the upper-parts and buff-brown on the rest of the body. The female lacks the black bib seen in males.

Family Sturnidae

Onychognathus tristramii (Sclater, 1858), Tristram's Starling

Figure 4

Porter and Aspinall (2010): 290; ITIS (2016).

Material examined. Table 1; field observations and photographs.

Identification. The male has glossy, specular black plumage, and the female has a gray-brown sooty head. A conspicuous orange color on the wing can be seen during flight and when perched.
Family Columbidae

Spilopelia senegalensis (Linnaeus, 1766), Laughing Dove

Figure 5

Porter and Aspinall (2010): 180; Pope and Zogaris (2012): 233; ITIS (2016).

Material examined. Table 1; field observations and photographs.

Identification. This species is common throughout Aldesa Valley. The head, breast, and neck are pink-mauve with black spots on the breast and white-gray plumage on belly and lower body. The upper body is deep red-brown with a black bill. Females look similar to males. 

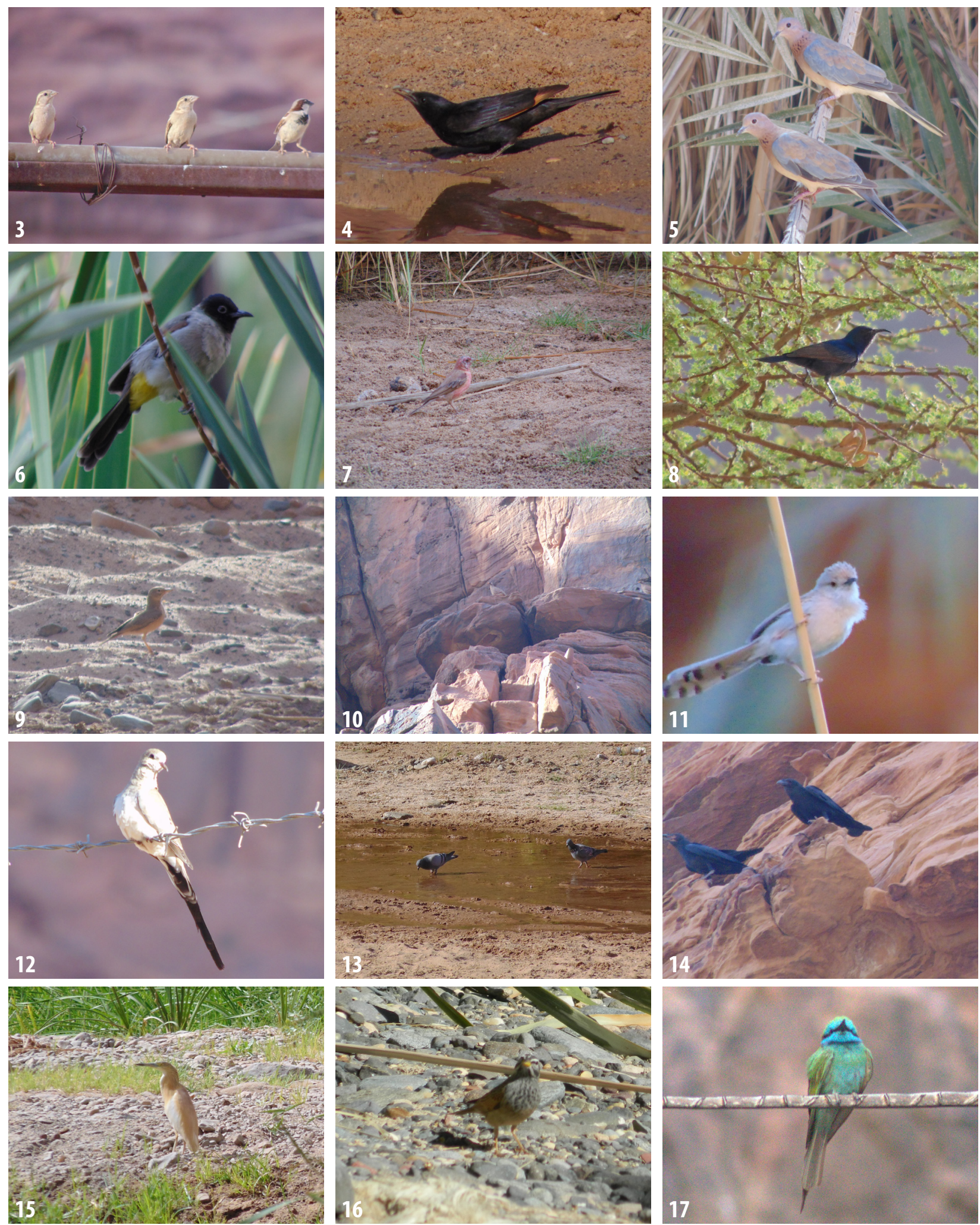

Figures 3-17. Birds detected during a terrestrial vertebrate inventory in Aldesa Valley, Saudi Arabia, May-August 2014-2015. 3. Passer domesticus, House Sparrows. 4. Onychognathus tristramii, Tristram's Starling. 5. Spilopelia senegalensis, Laughing Doves. 6. Pycnonotus xanthopygos, White-spectacled Bulbul. 7. Carpodacus synoicus, Sinai Rosefinch. 8. Cinnyris osea, Palenstine Sunbird. 9. Ammomanes deserti, Desert Lark. 10. Ammoperdix heyi, Sand Partridge. 11. Scotocerca inquieta, Streaked Scrub-Warbler. 12. Oena capensis, Namaqua Dove. 13. Columba livia, Rock Dove. 14. Corvus ruficollis, Brown-necked Raven. 15. Ixobrychus minutus, Little Bittern. 16. Emberiza striolata, House Bunting. 17. Merops orientalis, Green Bee-eater. Photographs by Abdulaziz Alatawi. 

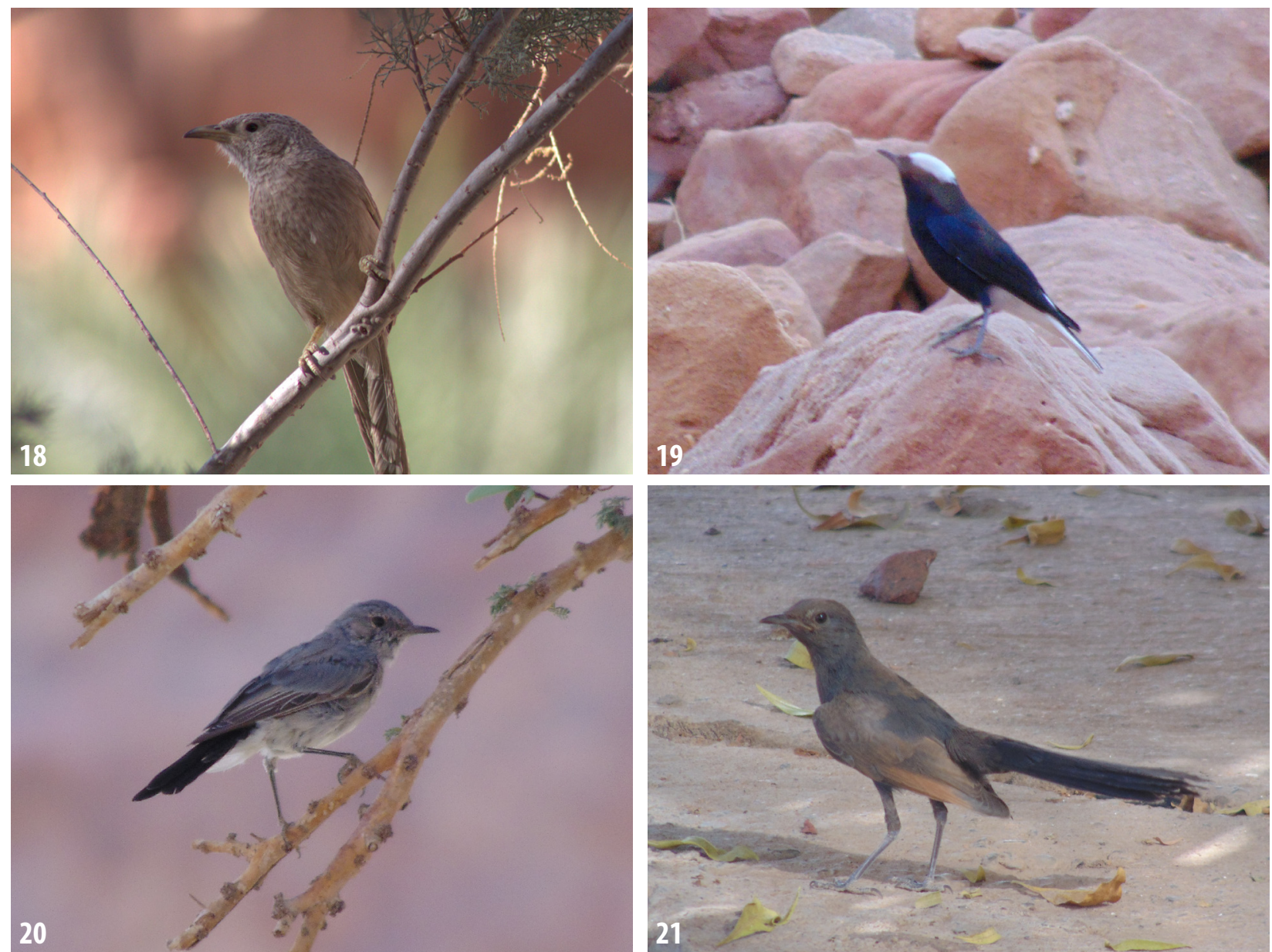

Figures 18-21. Birds detected during a terrestrial vertebrate inventory in Aldesa Valley, Saudi Arabia, May-August 2014-2015. 18. Argya squamiceps, Arabian Babbler. 19. Oenanthe leucopyga, White-crowned Wheatear. 20. Oenanthe melanura, Blackstart. 21. Cercotrichas podobe, Black Scrub-robin. Photographs by Abdulaziz Alatawi.

Family Pycnonotidae

\section{Pycnonotus xanthopygos (Hemprich \& Ehrenberg,} 1833), White-spectacled Bulbul

Figure 6

Porter and Aspinall (2010): 232; ITIS (2016).

Material examined. Table 1; field observations and photographs.

Identification. Pycnonotus xanthopygos is easy to identify with distinctive yellow plumage on the under-part of the body. The belly and breast are dull gray with a sooty black head. It has a black bill and is dark gray-brown on upper parts.

\section{Family Fringillidae}

Carpodacus synoicus Temminck, 1825, Sinai Rosefinch

Figure 7

Porter and Aspinall (2010): 354; ITIS (2016).

Material examined. Table 1, field observations and photographs.

Identification. The male of this species is very distinguishable and easy to identify. The body of the male is pink-rose in color with a sandy-brown tail. It has a conical-billed and the wings are pale-brown. The female is sandy-brown with sandy-pale buff underparts, faintly streaked on crown and mantle.

Family Nectariniidae

Cinnyris osea (Bonaparte, 1856), Palestine Sunbird Figure 8

Porter and Aspinall (2010): 322; ITIS (2016).

Material examined. Table 1; field observations and photographs.

Identification. This species has a long curved bill. Male has glossy blue-plumage on breast and dark black plumage on the rest of the body. Female has pale-gray on under-parts and brown-gray on the upper-parts. The bill of females is slightly longer than in males.

\section{Additional species}

Other species of birds observed were Ammomanes deserti (Lichtenstein, 1823 (Alaudidae, Desert Lark; Fig. 9), Ammoperdix heyi (Temminck, 1825) (Phasianidae; Sand Partridge; Fig. 10), Scotocerca inquieta (Cretzschmar, 1827) (Scotocercidae, Streaked scrub-Warbler; Fig. 11), 
Oena capensis (Linnaeus, 1766) (Columbidae, Namaqua Dove; Fig. 12), Columba livia Gmelin, 1789 (Columbidae, Rock Dove; Fig, 13), Corvus ruficollis Lesson, 1830 (Corvidae, Brown-necked Raven; Fig. 14), Ixobrychus minutus (Linnaeus, 1766) (Ardeidae, Little Bittern; Fig. 15), Emberiza striolata Lichtenstein, 1823 (Emberizidae, house bunting; Fig. 16), Merops orientalis Latham, 1801 (Meropidae, Green Bee-eater; Fig. 17), Argya squamiceps (Cretzschmar, 1827) (Leiotrichidae: Arabian Babbler; Fig. 18), Oenanthe leucopyga (Brehm, 1855) (Muscicapidae; White-crowned Wheatear; Figure 19), Oenanthe melanura (Temminck, 1824) (Muscicapidae, Blackstart; Fig. 20), Cercotrichas podobe (Müller, 1776) (Muscicapidae, Black Scrub-robin; Fig. 21).

The IUCN threat category for all species of birds observed is Least Concern (IUCN 2016).

\section{Discussion}

We detected 19 species of birds belonging to 15 families in the Aldesa Valley. Limited knowledge about species abundance and composition makes comparisons of species detected in Aldesa Valley difficult. Habitat heterogeneity typically provides diverse food resources; thus, higher species richness is expected in areas with such characteristics (Tews et al. 2004). The lower annual rainfall in deserts results in extreme drought most of the year and lower biodiversity (e.g. Arabian Peninsula; AbuZinada et al. 2004). Water, vegetation, and topography are key factors for species persistence in the extreme environmental conditions experienced in hot deserts (Tews et al. 2004, Korine et al. 2015). Perennial streams are rare in extreme desert environments, including Saudi Arabia (AbuZinada et al. 2004), which makes the Aldesa Valley unique. We suggest the habitat diversity in Aldesa Valley created by topography, vegetation, and especially permanent water is largely responsible for high avian species richness observed. Overall, there is a positive and fundamental relationship between habitat heterogeneity and species richness (Tews et al. 2004, Qian 2007).

We observed what we consider high avian species richness in Aldesa Valley, documenting 15 different families that accentuate the importance of this valley in the region. Such unique areas will likely benefit long term from increased official attention to help ensure species persistence and ecosystem function.

The Ministry of Tourism classified Aldesa Valley as a place for tourism in the Tabuk region (Saudi Commission for Tourism and Antiquities 2015). However, such a designation carries with it potential adverse consequences for the environment and biodiversity. Through this fieldwork and observations, we observed that tourism is causing negative effects on this ecosystem, as elsewhere in the world (Christ et al. 2003).

We observed numerous human activities in Aldesa valley that may adversely affect wildlife, including deposition of trash from tourists, occurrence of farms, and burning of trees. These human activities can influence ecological processes and landscape conditions which can adversely affect species richness and endemism (Vitousek et al. 1997, Hunter and Gibbs 2007). There is potential for adversely affecting biodiversity if these disturbances continue.

Because of the uniqueness of the Aldesa Valley, we suggest that avian biodiversity conservation of this area should be a priority. We encourage authorities to consider monitoring human activities in this unique valley (Al-Moutirti 2004) to ensure long-term persistence of avian assemblages. We encourage additional inventories, including more detailed studies (e.g. night counts focusing on nocturnal species) on avian and other vertebrate groups, and ecological studies to further our understanding of the vertebrate community structure, dynamics, and species interactions in the Aldesa Valley.

\section{Acknowledgements}

We thank everyone that directly or indirectly participated in this project. Tabuk University provided scholarship support. We thank J. Gallardo for assistance with bird identifications.

\section{Authors' contributions}

ASA, FB, and JLB designed the survey. ASA conducted the survey, collected the data, and identified the specimens. ASA, FB, and JLB wrote the text.

\section{References}

AbuZinada AH, Robinson ER, Nader IA, Al-Wetaid YI (2004) First Saudi Arabian National Report on the Convention on Biological Diversity. The National Commission for Wildlife Conservation and Development, Riyadh, 131 pp.

Al-Moutiri M (2004) The diversity of fauna in the Ibex Reserve. Master thesis, Riyadh, Saudi Arabia, King Saud University, 390 pp.

Balvanera P, Pfisterer AB, Buchmann N, He J, Nakashizuka T, Raffaelli D, Schmid B (2006) Quantifying the evidence for biodiversity effects on ecosystem functioning and services. Ecology Letters 9: 1146-1156. https://doi.org/10.1111/j.1461-0248.2006.00963.x

Brooks TM, Mittermeier RA, Fonseca GB, Gerlach J, Hoffmann M, Lamoreux JF, Mittermeier CG, Pilgrim JD, Rodrigues AL (2006) Global biodiversity conservation priorities. Science 313: 58-61. https://doi.org/10.1126/science.1127609

Brown RL, Jacobs LA, Peet RK (2007) Species richness: small scale. Encyclopedia of Life Sciences (eLS): 1-8. https://doi. org/10.1002/9780470015902.a0020488

Catalogue of Life (2016) http://www.catalogueoflife.org. Accessed on: 2016-03-24.

Chapin III FS, Zavaleta ES, Eviner VT, Naylor RL, Vitousek PM, Reynolds HL, Hooper DU, Lavorel S, Sala OE, Hobbie SE, Mack MC, Díaz S (2000) Consequences of changing biodiversity. Nature 405: 234-242. https://doi.org/10.1038/35012241

Christ C, Hillel O, Matus S, Sweeting J (2003) Tourism and Biodiversity: Mapping Tourism's Global Footprint. Conservation International and UNEP, Washington DC, $53 \mathrm{pp}$.

Fa JE, Funk SM (2007) Global endemicity centers for terrestrial vertebrates: an ecoregions approach. Endangered Species Research 3: 31-42. https://doi.org/10.3354/esr003031

Gaston KJ (2000) Global patterns in biodiversity. Nature 405: 220-227. https://doi.org/10.1038/35012228 
Gillman LN, Wright SD (2014) Species richness and evolutionary speed: the influence of temperature, water and area. Journal of Biogeography 41: 39-51. https://doi.org/10.1111/jbi.12173

Gosling SN, Dunn R, Carrol F, Christidis N, Fullwood J, Gusmao DD, Golding N, Good L, Hall T, Kendon L, Kennedy J et al. (2011) Climate: Observations, Projections and Impacts: Saudi Arabia. The Met Office, Nottingham, 114 pp.

Groombridge B, Jenkins M (2002) World Atlas of Biodiversity: Earth's Living Resources in the 21st Century. UNEP World Conservation Monitoring Centre. University of California Press, Berkeley, 360 pp.

Hill D, Fasham M, Tucker G, Shewry M, Shaw P (2005) Handbook of Biodiversity Methods: Survey, Evaluation and Monitoring. Cambridge University Press, New York, 573 pp.

Hunter ML, Gibbs JP (2007) Fundamentals of Conservation Biology,3rd eEdition. Blackwell Publishing, 515 pp.

IUCN (2016) IUCN Red List of Threatened Species. International Union for Conservation of Nature. http://www.iucnredlist.org. Accessed on: 2016-10-01.

Jetz W, Thomas GH, Joy JB, Hartmann K, Mooers AO (2012) The global diversity of birds in space and time. Nature 491: 444-448. https://doi.org/10.1038/nature11631

Korine C, Adams AM, Shamir U, Gross A (2015) Effect of water quality on species richness and activity of desert-dwelling bats. Mammalian Biology 80: 185-190. https://doi.org/10.1016/j.mambio.2015.03.009

Lawrence K (2004) Life in the Desert: Life in Extreme Environments. Rosen Publishing Group, New York, 64 pp.

Pimm SL, Jenkins CN, Abell R, Brooks TM, Gittleman JL, Joppa LN, Raven PH, Roberts CM, Sexton JO (2014) The biodiversity of species and their rates of extinction, distribution, and protection. Science 344: 1246752. https://doi.org/10.1126/science.1246752

Pope M, Zogaris S (2012) Birds of Kuwait: A Comprehensive Visual Guide. KUFPEC, Biodiversity East, Cyprus, 413 pp.

Porter R, Aspinall S (2010) Birds of the Middle East, 2nd edition. Princeton University Press, Princeton, 376 pp.

Qian H (2007) Relationships between plant and animal species richness at a regional scale in China. Conservation Biology 21: 937-944. https://doi.org/10.1111/j.1523-1739.2007.00692.x
Ralph C, Droege S, Sauer JR (1995) Managing and monitoring birds using point counts: standards and applications. USDA Forest Service General Technical Report. PSW-GTR-149: 161-169.

Sala, OE, Chapin III FS, Armesto JJ, Berlow E, Bloomfield J, Dirzo R, Huber-Sanwald E, Huenneke LF, Jackson RB, Kinzig A, Leemans R, Lodge DM, Mooney HA, Oesterheld M, Poff N, Sykes M, Walker B, Walker M, Wall D (2000) Global biodiversity scenarios for the year 2100. Science 287: 1770-1774. https://doi. org/10.1126/science.287.5459.1770_

Saudi Commission for Tourism and Antiquities (2015) http://www.scta. gov.sa. Accessed on: 2015-10-11.

Shirley SM, Yang Z, Hutchinson RA, Alexander JD, McGarigal K, Betts MG (2013) Species distribution modeling for the people: unclassified landsat TM imagery predicts bird occurrence at fine resolutions. Diversity and Distributions 19: 855-866. https://doi. org/10.1111/ddi.12093

Slattery BE, Reshetiloff K, Zwicker SM (2003) Native Plants for Wildlife Habitat and Conservation Landscaping: Chesapeake Bay Watershed. U.S. Fish \& Wildlife Service, Chesapeake Bay Field Office, Annapolis, 82 pp.

Tews J, Brose U, Grimm V, Tielborger K, Wichmann MC, Schwager M, Jeltsch F (2004) Animal species diversity driven by habitat heterogeneity/diversity: the importance of keystone structures. Journal of Biogeography 31: 79-92. https://doi.org/10.1046/j.03050270.2003.00994.x

Tiger BJ, Osborne PE (1999) The influence of the lunar cycle on ground-dwelling invertebrates in an Arabian desert. Journal of Arid Environments 43: 171-182. https://doi.org/10.1006/jare.1999.0541

Vitousek PM, Mooney HA, Lubchenco J, Melillo JM (1997) Human domination of Earth's ecosystems. Science 277: 494 499. https:// doi.org/10.1126/science.277.5325.494

Waide RB, Willig MR, Steiner CF, Mittelbach G, Gough L, Dodson SI, Juday GP, Parmenter R (1999) The relationship between productivity and species richness source. Annual Review of Ecology and Systematics 30: 257-300. https://doi.org/10.1146/annurev. ecolsys.30.1.257

Walker A (1992) Deserts: Geology and Resources. U.S. Geological Survey, Government Printing Office, Denver 64 pp. 